\title{
PENGGUNAAN PERALATAN LISTRIK RUMAH TANGGA SECARA HEMAT PADA MASYARAKAT DESA WUSA KECAMATAN TALAWAAN
}

\author{
Billy M. H. Kilis \\ Program Studi Pendidikan Teknik Elektro, Fakultas Teknik, \\ Universitas Negeri Manado (UNIMA) \\ billymorriskilis@gmail.com
}

\begin{abstract}
Abstrak
Partisipasi Masyarakat dalam Program hemat energy listrik. 'Program konservasi energi dalam bentuk Demand Side Management (DSM) tidak akan berhasil tanpa adanya partisipasi masyarakat," ujar Menteri Energi dan Sumber Daya Mineral (ESDM) Purnomo Yusgiantoro saat membuka acara Seminar Konservasi Energi dengan Tema Penerapan Program Konservasi Energi Pada bangunan (Best Practice), Kamis (3/8) di Jakarta. Menteri ESDM Purnomo Yusgiantoro mengungkapkan sudah saatnya masyarakat disadarkan bahwa perilaku hemat energi bukan hanya berguna bagi Pemerintah. Namun juga bagi pelaku hemat energi itu sendiri. "Sebab, rekening listrik bisa rendah misalnya. Permasalahan yang diidentifikasi dari mitra yaitu warga produktif dan yang berkaitan dengan penggunaan energi listrik yang masih cenderung boros. penggunaan peralatan listrik yang semakin memasyarakat belum didukung oleh upaya prilaku yang hemat. Metode yang digunakan untuk menjawab permasalahan mitra yaitu pelatihan, simulasi dan pendampingan. Adanya penurunan pemakaian energy listrik yang diperoleh pada pembayaran sebulan baik untuk listrik prabayar maupun pasca bayar. Publikasi ilmiah yang akan diterbitkan melalui jurnal. Peningkatan pendapatan akibat berkurangnya biaya pemakaian energy listrik. Pemakaian yang lebih ekonomis. Pemahaman yang lebih utuh mengenai pemakaian energy listrik yang benar, lebih hemat dan terencana.
\end{abstract}

Kata Kunci: Hemat listrik.

\section{PENDAHULUAN}

Sejalan dengan pertumbuhan ekonomi di Indonesia, maka kebutuhan akan energy terus bertumbuh mengikuti pertumbuhan ekonomi tersebut. Di sisi lain ketersediaan sumber listrik dan infra struktur kelistrikan belum bertumbuh sebagaimana yang diharapkan. Oleh karena itu perlu adanya peran masyarakat dalam hal upaya dan partisipasi dalam penghematan energi listrik. Upaya tersebut perlu dilakukan di desa maupun pinggiran kota hingga kota-kota besar. Desa Wusa berada pada area sekitar Bandara Internasional Sam Ratulangi yang terletak di Kecamatan Talawaan Kabupaten
Minahasa Utara. Desa ini secara geografis memiliki iklim tropis basah dan berada pada ketinggian $\pm 100 \mathrm{~m}$ di atas permukaan laut, dengan luas wilayah $10,30 \mathrm{Km}^{2}$.

Batas-batas wilayah administrasi yaitu: sebelah Utara dengan Desa Warisa, sebelah Selatan dengan Desa Winetin dan Kecamatan Mapanget, sebelah Timur berbatasan dengan Desa Teep Warisa, Desa Patokaan dan Desa Tombohon, sebelah Barat berbatasan dengan Kecamatan Mapanget. Desa Wusa memiliki 6 jaga yang masing-masing dipimpin oleh seorang kepala jaga dan pada sensus memiliki jumlah penduduk 1.146 jiwa, terdiri dari 
606 laki-laki dan 540 perempuan. Kepadatan penduduk sebesar 111,6 jiwa per $\mathrm{Km}^{2}$, mata pencaharian utama penduduk desa sebagai petani, peternak, tukang bangunan dan lainnya termasuk sebagai wiraswasta, PNS/TNI, swasta. Keadaan desa yang berada di sekitar bandara menyebabkan mobilitas masyarakat relatif tinggi dan berpengaruh pada penggunaan energi listrik yang juga cenderung boros. Kebanyakan penduduk selain bekerja di desa juga bekerja di bandara atau sekitarnya, bahkan di kota Manado. Oleh karena itu sebagian besar penduduk atau warga sangat dipengaruhi oleh pola hidup yang konsumtif.

Sasaran utama program ini yaitu ibu-ibu dan generasi muda yang dianggap paling sering menggunakan dan memanfaatkan energi listrik. Pada umumnya generasi muda masih belum memahami penggunaan energi listrik yang hemat, disisi lain ketersediaan listrik masih relatif terbatas. Secara geografis wilayah desa Wusa Kecamatan Talawaan Kabupaten Minahasa Utara, berbatasan dengan Kota Manado dalam hal ini Kecamatan Mapanget. Desa ini termasuk daerah penyanggah kota dari segi letak, dan juga sangat berdekatan dengan Bandara Internasional Sam Ratulangi. Posisi strategis desa ini mau atau tidak sangat dipengaruhi oleh faktor eksternal yang ada dari Manado maupun dari keberadaan bandara. Posisi yang demikian mengakibatkan pola hidup yang relatif dinamis dalam meemanfaatkan energi. Di sisi lain perilaku masyarakat terhadap hemat energi masih relatif rendah. ketersediaan energi yang masih terbatas, menyebabkan seringnya terjadi pemadaman listrik di wilayah dimaksud. Oleh karena itu perlu didukung oleh keterlibatan masyarakat dalam upaya penghematan energi listrik. Sebagian yang memanfaatkan teknologi yaitu warga yang bersekolah dan bekerja di Manado.

Permasalahan yang diidentifikasi dari mitra yaitu warga produktif dan yang berkaitan dengan penggunaan energi listrik yang masih cenderung boros. Penggunaan peralatan listrik yang semakin memasyarakat belum didukung oleh upaya prilaku yang hemat. Pada setiap kelompok masyarakat atau dalam keluarga, teridentifikasi pengguna utama yang dominan yaitu ibuibu rumah tangga dan anak-anak atau generasi muda. Sedangkan ayah, bapakbapak lebih cenderung lebih lama berada di luar rumah, sehingga penggunaannya juga relatif kurang. Dari survey waktu penggunaan energi listrik rumah tangga teridentifikasi sebagai berikut:

Tabel 1. Perilaku pengguna menurut waktu (persentase penggunaan)

\begin{tabular}{llll}
\hline No & $\begin{array}{l}\text { Kelompok/ } \\
\text { individu } \\
\text { Pengguna }\end{array}$ & $\begin{array}{l}\text { Waktu } \\
\text { penggunaan }\end{array}$ & Lama/\% \\
\hline 1 & Ibu-ibu & $06.00-20.00$ & $\begin{array}{l}14 \text { jam } \\
(58,3)\end{array}$ \\
\hline 2 & Anak-anak & $14.00-22.00$ & $\begin{array}{l}8 \text { jam } \\
(33)\end{array}$ \\
\hline 3 & Bapak/ayah & $18.00-22.00$ & $\begin{array}{l}4 \text { jam } \\
(16)\end{array}$ \\
\hline 4 & Lainnya & Relatif & $\begin{array}{l}4 \text { jam } \\
(16)\end{array}$ \\
\hline
\end{tabular}

Sumber : Hasil survey Tahun 2016 
Dari identifikasi tersebut ibu-ibu maupun anak-anak paling dominan menggunakan energi listrik. Namun demikian pada ibu-ibu lebih cenderung pada penggunaan yang bermanfaat, seperti kebutuhan memasak, menyeterika dan menonton Televisi. Oleh karena itu mengatasi masalah tersebut perlu adanya penjelasan pada dua komponen keluarga yaitu ibu-ibu dan generasi muda.

\section{KAJIAN LITERATUR}

Konsumsi Energi Listrik di Indonesia, semakin bertumbuh sejalan dengan kemajuan dan pertumbuhan ekonomi. Data dari PT PLN (Persero) mencatatkan penjualan listrik sebesar 17,57 Terra Watt Hour (TWh) di sepanjang Januari 2016, meningkat 7,54 persen dibandingkan penjualan listrik di periode yang sama tahun lalu pada angka 16,34 TWh. Pelaksana Tugas Kepala Satuan Komunikasi Korporat PLN, Agung Murdifi menjelaskan, pertumbuhan penjualan listrik di medio Januari 2015 terjadi dari berbagai segmen tarif, dua di antaranya pelanggan golongan bisnis dan industri. Dalam catatan PLN, di sepanjang bulan pertama tahun ini angka penjualan listrik golongan bisnis diketahui mengalami peningkatan sebesar 10,47 persen, sehingga golongan dengan tarif bisnis berkontribusi dalam 17,7 persen dari total penjualan. Sementara untuk golongan industri, Agung menyatakan di sepanjang Januari 2016 angka penjualan mengalami pertumbuhan
2,28 persen atau meningkat 6,59 persen dibandingkan angka penjualan pada Desember 2015 yang berada di posisi minus 4,31 persen. Melalui capaian ini, PLN pun mengklaim telah terjadi pemulihan kondisi industri skala besar. "Semakin tingginya penjualan listrik di golongan industri maupun bisnis, menunjukkan semakin banyak pula industri dan bisnis yang beroperasi. Maka diharapkan tenaga kerja akan semakin cepat terserap," ujarnya di Jakarta, Rabu (17/2). Dikutip CNN dalam berita 20 Januari 2015. Pada bagian selanjutnya Agung merinci, penjualan listrik ke golongan industri besar pada medio Januari 2016 mencapai 1.187.264.579 kWh atau meningkat 6,49 persen dari periode yang sama tahun lalu di posisi minus 0,28 persen. Dimana peningkatan angka penjualan listrik pada golongan tersebut disumbang oleh peningkatan konsumsi pada industri tekstil, ban, semen, baja, elektronik, serat sintetis, dan kimia. Ia mengatakan, salah satu faktor yang mempengaruhi meningkatnya penjualan listrik di sektor ini ialah turunnya tarif listrik golongan industri sebesar 4,1 persen dibandingkan Januari 2015. Pertumbuhan penjualan ini diikuti oleh sektor industri sedang yang juga mengalami penurunan tarif sebe-sar 6,5 persen di Januari 2016. "Faktor lain yang mempengaruhi meningkatnya penjualan di golongan ini adalah adanya Paket Ekonomi jilid III pada Oktober 2015 yaitu program promo LWBP (Luar Waktu Beban Puncak) 23.00- 
08.00 WIB. Kebijakan ini disambut positif oleh pasar," imbuh Agung. CNN dalam berita 20 Januari 2015 (website Peran Masyarakat dalam upaya hemat energy. Download Tgl.13 Agustus 2017. Jam 16.15 wita.

Banyak sekali kegunaan energi listrik dalam kehidupan manusia. Listrik sudah menjadi kebutuhan utama bagi manusia dalam kehidupan sehari-hari. Sehingga dapat dikatakan, tidak banyak yang dapat diperbuat oleh manusia tanpa adanya energi listrik. Perkembangan ilmu pengetahuan dan teknologi dewasa ini tak luput dari penggunaan energi listrik. Ini sudah diketahui semua orang sejak dulunya. Di bangku pendidikan, pelajaran tentang listrik sudah diperkenalkan lebih detail pada siswa sejak kelas IX jenjang SMP/Sederajat dan harus ditingkatkan pada jenjang selanjutnya. Pelajaran ini tidak hanya membahas tentang seluk beluk listrik dinamis melainkan juga bagaimana penggunaan sumberdaya listrik di rumah tangga.

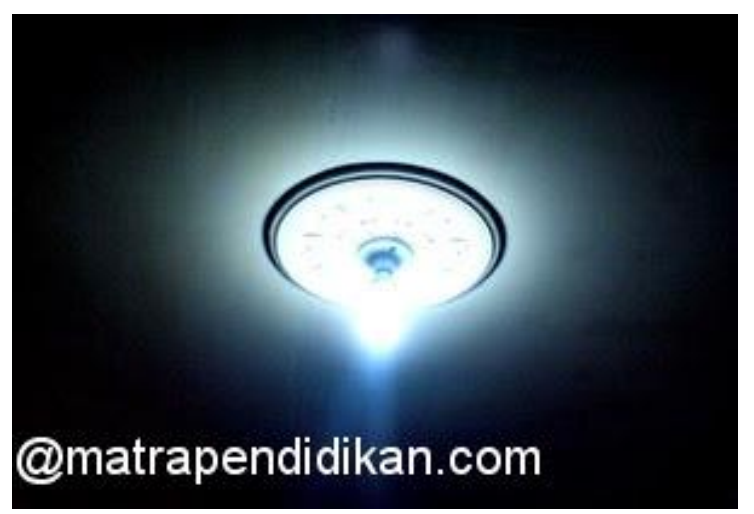

Gambar 1. Pengingat pentingnya hemat listrik dengan penggunaan LHE untuk pendidikan.
Pada Gambar 1 tampak model pembelajaran tentang penggunaan Lampu Hemat Energi, bagi siswa. Sasaran utama pelajaran energi listrik adalah bagaimana siswa menggunakan energi listrik secara benar di rumah masing-masing. Rupanya akhir-akhir ini, energi listrik bukanlah sumberdaya yang bebas dipakai dan mudah didapat dan murah sehingga harus dihemat. Hal tersebut sejalan dengan prinsip konservasi yang menurut Scott dalam Kruttila (1987), kegiatan penghematan merupakan kebijakan yang bertujuan mengembangkan pasokan sumber daya alam dan energi untuk masa mendatang. Ketersediaan energi listrik semakin terbatas karena penggunanya juga semakin bertambah dari hari ke hari. Inilah yang melatarbelakangi mengapa pentingnya sebuah gerakan untuk menghemat energi listrik yang dimulai dari setiap rumah tangga pengguna energi listrik. Hemat listrik bukan berarti pelit dengan listrik, atau membatasi penggunaan energi listrik di rumah tangga. Hemat listrik berarti menggunakan energi listrik dengan bijaksana dan sesuai kebutuhan. Energi listrik digunakan menganut prinsip dimana dan kapan perlu saja. Gunakan energi listrik dimana perlu saja. Ini menyangkut konsep pemasangan alat-alat listrik di rumah tangga. Sedangkan kapan perlu saja berkaitan dengan efesiensi penggunaan alat listrik yang dibutuhkan.

Gerakan hemat energi listrik dimulai dari rumah tangga. Anggota keluarga ber- 
tanggung-jawab atas penggunaan energi listrik. Sementara itu kedua orang tua perlu arif dan bijaksana dalam mengelola penggunaan listrik sehingga tagihan listrik dapat dibayarkan secara efektif dan wajar. "Program konservasi energi dalam bentuk Demand Side Management (DSM) tidak akan berhasil tanpa adanya partisipasi masyarakat," ujar Menteri Energi dan Sumber Daya Mineral (ESDM) Purnomo Yusgiantoro saat membuka acara Seminar Konservasi Energi dengan Tema Penerapan Program Konservasi Energi Pada bangunan (Best Practice), Kamis (3/8) di Jakarta. Menteri ESDM Purnomo Yusgiantoro, ketika itu mengungkapkan sudah saatnya masyarakat disadarkan bahwa perilaku hemat energi bukan hanya berguna bagi Pemerintah. Namun juga bagi pelaku hemat energi itu sendiri.

Tabel. 2. Cara Konservasi Energi Listrik di Rumah Tangga

\begin{tabular}{|c|c|c|}
\hline No. & $\begin{array}{l}\text { Cara konservasi } \\
\text { Housekeeping }\end{array}$ & $\begin{array}{l}\text { Cara Retrofitting/ } \\
\text { Replacement }\end{array}$ \\
\hline 1 & $\begin{array}{lr}\text { Matikan lampu } \\
\text { jika } \\
\text { diperlukan }\end{array}$ & $\begin{array}{l}\text { Gunakan lampu hemat } \\
\text { listrik }\end{array}$ \\
\hline 2 & $\begin{array}{l}\text { Matikan TV, jika } \\
\text { tidak menonton }\end{array}$ & $\begin{array}{l}\text { Gunakan kulkas hemat } \\
\text { listrik }\end{array}$ \\
\hline 3 & $\begin{array}{lr}\text { Matikan } & \text { Radio } \\
\text { jika } & \text { tidak } \\
\text { dipakai } & \\
\end{array}$ & $\begin{array}{l}\text { Gunakan AC sesuai } \\
\text { ukuran ruangan }\end{array}$ \\
\hline 4 & $\begin{array}{l}\text { Atur suhu } \\
\text { kulkas sesuai } \\
\text { kebutuhan }\end{array}$ & $\begin{array}{l}\text { Gunakan tangka } \\
\text { penampungan air } \\
\text { untuk pompa listrik }\end{array}$ \\
\hline 5 & $\begin{array}{l}\text { Atur suhu AC } \\
\text { sesuai } \\
\text { kebutuhan }\end{array}$ & $\begin{array}{l}\text { Gunakan setrika } \\
\text { dengan regulator }\end{array}$ \\
\hline 6 & $\begin{array}{l}\text { Atur AC } \\
\text { menggunakan } \\
\text { timer. }\end{array}$ & $\begin{array}{l}\text { Gunakan semua } \\
\text { peralatan dengan label } \\
\text { hemat dan berstandar } \\
\text { SNI. }\end{array}$ \\
\hline
\end{tabular}

Pada table 2, beberapa peralatan sebagai contoh, karena ada lebih banyak peralatan listrik yang murah dan digunakan di rumah tangga. Pengalaman ini perlu disampaikan kepada teman maupun sejawatnya untuk selanjutnya melakukan hal yang sama," ujar Menteri ESDM Purnomo Yusgiantoro. Diungkapkan bahwa kondisi saat ini sudah tidak bisa lagi mengandalkan atau tergantung terhadap sumber energi minyak bumi. Selain jumlah cadangan semakin menurun sehingga produksi berat dinaikkan, jumlah konsumsi BBM pun semakin bertambah. Oleh sebab itu harus didodorng konservasi maupun diversifikasi energi. Dalam implementasi konservasi energi, tantangan besar yang dihadapi pemerintah diantaranya adalah penyamaan persepsi masyarakat mengenai pentingnya pelaksanaan konservasi energi. Sumber energi permbangkitan di Indonesia masih bertumpu pada minyak bumi, gas bumi, batu bara, panas bumi dan air (Yusgiantoro : 2000). Konservasi energi merupakan upaya Pemerintah dalam melestarikan sumber daya energi serta meningkatkan efisiensi pemanfaatannya. Oleh karenanya, pelaksanaan konservasi energi memerlukan partisipasi dari semua elemen masyarakat. Konservasi energi adalah penggunaan sumber daya energi demi kepentingan generasi mendatang atau disimpulkan penggunaan yang hemat (Pinchot dalam Reksohadiprodjo dan Pradono (1988). Selanjutnya Kadir (1989), mendefinisikan sebagai pemanfaatan sumber daya alam 
dengan daya guna yang lebih tinggi melalui cara-cara layak secara teknis dan ekonomis. Selain pembangunan perilaku, konservasi energi sangat dipengaruhi oleh perkembangan teknologi yang semakin lama semakin cepat dan secara langsung dalam mempengaruhi pemanfaatan energi. Parlemen Perancis akan mengeluarkan Undangundang bahwa mulai tahun 2040 Perancis akan menghentikan kendaraan-kendaraan berbahan bakar minyak. "Mereka akan beralih ke kendaraan listrik" jelas Hadi M. Djuarid Staf Khusus Menteri Bidang Komunikasi Kementerian ESDM yang juga memberikan sambutan terkait acara tersebut.

\section{METODE PELAKSANAAN}

Untuk melaksanakan kegiatan dimaksud, maka langkah-langkah yang akan dilakukan untuk solusi pertama yaitu:

1. Menyusun rancangan pelaksanaan kegiatan $\quad \mathrm{I}_{b} \mathrm{M} / \mathrm{PKM}$ ) (Program Kemitraan Masyarakat);

2. Berkomunikasi dengan pemerintah desa melalui Kepala desa Wusa untuk sosialisasi kegiatan $\mathrm{I}_{\mathrm{b}} \mathrm{M}$./PKM;

3. Penanda-tangan surat kerjasama dengan mitra;

4. Menghubungi aparat desa/warga yang direkomendasi untuk ikut program; dan

5. Menentukan waktu pelaksanaan.

Untuk melaksanakan solusi yang kedua, dapat dilakukan dengan cara:

1. Pemberian materi hemat energi;
2. Tanya jawab;

3. Simulasi;

4. Tugas/Latihan; dan

5. Menghitung daya yang terpakai. (evaluasi).

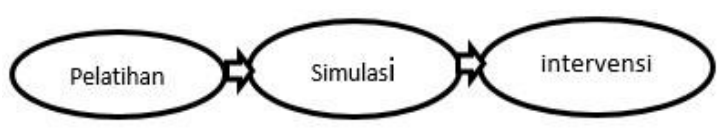

Gambar 2. Metode pendekatan mengubah perilaku masyarakat.

Melaksanakan solusi ketiga, maka langkah-langkah yang akan ditempuh yaitu:

1. Melakukan pendampingan terhadap peserta, dalam menyusun buku sesuai kebutuhan dan mudah digunakan masyarakat. Metode yang digunakan untuk menjawab permasalahan mitra yaitu pelatihan, simulasi dan pendampingan;

2. Pelatihan sederhana dalam hal penggunaan peralatan listrik rumah-tangga;

3. Melakukan simulasi dan demonstrasi langsung; dan

4. Melakukan upaya pendampingan atau intervensi untuk mengubah perilaku dan evaluasi pemakaian listrik baik dengan listrik prabayar maupun konvensional. Intervensi dilakukan setelah adanya evaluasi peelaksanaan yang melibatkan perangkat desa/kelurahan.

\section{HASIL DAN PEMBAHASAN}

Kegiatan pengabdian ini dilaksanakan pada hari Sabtu Tgl. 4 Agustus 2017, di Balai Desa Wusa Kecamatan Talawaan Kabupaten 
Minahasa Utara. Praktek Pelaksanaan di Evaluasi 1 sampai 2 bulan kemudian dengan mencatatkan hasil pemakaian energi melalui pembayaran rekening listrik. Pada listrik prabayar dihitung berapa biaya pembelian pulsa listrik rata-rata dalam sebulan sehingga pada akhirnya memberikan dampak ekonomi bagi setiap rumah tangga.

Proses penyajian dilakukan dalam bentuk ceramah, pengenalan alat hemat listrik dan praktek sederhana. Pemberian contoh penghitungan meter listrik atau dilihat selisih pembayaran sebagai pengaruh dari upaya penghematan penggunaan peralatan listrik rumah tangga. Sebagai bentuk evaluasi setiap peserta melaporkan hasil pemakaian listrik kepada kepala desa melalui kepala lingkungan/kepala jaga. (perangkat desa). Hasilnya kemudian disampaikan kepada Tim pernyaji.

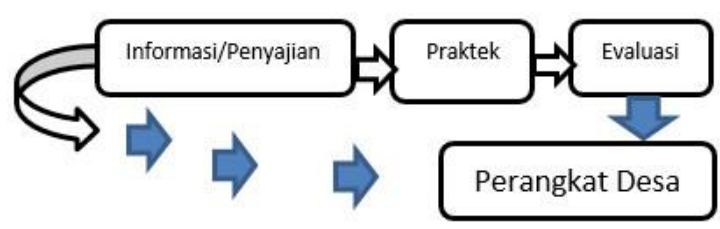

Gambar 3. Teknik pelaksanaan PKM.

Pelaksanaan kegiatan pengabdian yang dilakukan pada hari sabtu memiliki kendala waktu dimana pada akhir pecan banyak keluarga melakukan aktivitas di rumah masing-masing, sehingga perlu di cari waktu yang tepat. Pelaksanaan harus dilakukan paling kurang 4 kali setiap akhir pecan atau waktu yang tepat, sehingga lebih efektif. Kehadiran lebih banyak ibu-ibu rumah tangga yang memang secara tidak langsung merupakan sasaran strategis pada pengguna listrik dominan di rumah.

Sesuai rencana beberapa capaian yang diperoleh yaitu:

1. Adanya penurunan pemakaian energi listrik yang diperoleh pada pembayaran sebulan baik untuk listrik prabayar maupun pasca bayar (Data bulan September);

2. Publikasi ilmiah yang akan diterbitkan melalui jurnal;

3. Peningkatan pendapatan akibat berkurangnya biaya pemakaian energi listrik;

4. Pemakaian yang lebih ekonomis; dan

5. Pemahaman yang lebih utuh mengenai pemakaian energi listrik yang lebih hemat dan terencana.

\section{KESIMPULAN DAN SARAN}

Pelaksanaan kegiatan pengabdian pada masyarakat agar melibatkan masyarakat yang sesuai dengan sasaran dibutuhkan perencanaan yang matang dan melibatkan seluruh perangkat Desa mitra. Kepala Desa harus memberikan pemahaman awal tentang rencana dan dampak positif ketika mengikuti. Beberapa kendala dalam pelaksanaan yaitu waktu mulai yang belum tepat waktu, serta kurang siapnya masyarakat ketika memulai kegiatan. Oleh karena itu perlu adanya kegiatan awal mendahului kegiatan utama, sehingga diperoleh hasil 
yang lebih optimal. Beberapa simpulan dalam pelaksanaan kegiatan ini yaitu: Masih relatif banyak masyarakat yang belum memahami penggunaan listrik secara hemat dan benar. Sebagian besar masyarakat masih menggunakan lampu yang belum memenuhi standar hemat. Belum adanya kesadaran memilih peralatan yang hemat dan dapat mengurangi biaya operasional sehari-hari. Masih terlalu banyak masyarakat yang tanpa sadar menggunakan energi listrik pada jam-jam beban puncak untuk hal-hal yang kurang penting, seperti menyeterika pada malam hari, menyeterika setiap waktu, bahkan memasang lampu untuk semua ruangan yang tidak bermanfaat. Setiap warga masyarakat mulai memperhatikan penggunaan energi listrik secara benar dan hemat. Perlu adanya kesadaran bersama dalam satu keluarga untuk berupaya berhemat dalam pemakaian energi. Perlu adanya kemitraan yang terus-menerus antara perguruan tinggi dengan masyarakat.

\section{KEPUSTAKAAN}

Kilis, B. 2003. Konservasi Energi Listrik di Kecamatan Wanea Kota Manado. Tesis Pascasarjana Unsrat.

Kadir, A. 1989. Energi. Jakarta: Universitas Indonesia Press.

Kruttila, J. V. 1987. Conservation Reconsidered. The American Economic Review.

Reksohadiprodjo, S., \& Pradono. 1988. Ekonomi Sumberdaya Alam dan Energi. BPFE Jogyakarta.

Yusgiantoro, P. 2000. Ekonomi Energi. Teori dan Praktek. LP3ES.

Perpres No 47 Tahun 2017. Tentang Penyediaan Lampu Hemat Energi (LHE) bagi Masyarakat.

Peraturan Menteri ESDM No.33 Tahun 2017, Teentang Tata Cara Penyediaan LHE bagi Masyarakat.

http://www.Matra Pendidikan.com/2015/07. Pentingnya Gerakan Hemat Energi Listrik. Download Tgl.13 Agustus 2017. Jam 16.00 wita.

CNN dalam berita 20 Januari 2015. Peran Masyarakat dalam upaya hemat energy. Download Tgl.13 Agustus 2017. Jam 16.15 wita.

Pidato Bambang Wijatmoko, 13 Juli 2017 di Sekolah Muhamadiyah Jogyakarta tentang Konservasi Energi Listrik dan Pentingnya peran siswa. 